\title{
APRENDER A ESCRIBIR CON RUBÉN DARÍO: HACIA UNA PROPUESTA DE COMENTARIO DE TEXTOS ESENCIALES SOBRE LA RECEPCIÓN DEL MODERNISMO ENTRE LOS JÓVENES POETAS ESPAÑOLES
}

\author{
Víctor MANUEl SANCHIS AMAT \\ Universidad Católica San Antonio de Murcia
}

\section{Resumen}

En las líneas que siguen se plantea un ejercicio didáctico de comentario de textos literarios de tres poetas esenciales de la literatura española de la primera mitad del siglo XX. A partir de la definición de la poética dariana que estableciera Pedro Henríquez Ureña, el artículo presenta un comentario sobre las influencias formales y las perspectivas ideológicas herederas de la tradición modernista a partir de la reflexión sobre si Darío pudo o no escribir estos poemas y por qué. Se iniciarán los comentarios formales de los poemas sin desvelar el autor, para después insertar los contextos de producción y valorar también los tópicos modernistas en los jóvenes poetas españoles.

Palabras clave. Rubén Darío, Modernismo, Antonio Machado, Federico García Lorca, Miguel Hernández.

\begin{abstract}
On the following lines, a didactic activity is proposed as a literary commentary about three essential poets in Spanish literature from the first half of the 20th Century. Since Rubén Dario's poetic definition on, which was established by Pedro Henríquez Ureña, the article presents a commentary about the formal influences and the ideological perspectives inherited from the modernist based on the reflection whether Darío could have written or not these poems and why. On the first hand, we will include the formal comments on the poems without revealing the author; on the second hand, we will include their corresponding production contexts and, also appreciating the modernist topics in the young Spanish poets.
\end{abstract}


Keywords: Rubén Darío, Modernismo, Antonio Machado, Federico García Lorca, Miguel Hernández.

De cualquier poema en español puede decirse con precisión si se escribió antes o después de él. Sus admiradores sintieron la fascinación de sus imágenes llenas de color, su riqueza de alusiones literarias, su felicidad verbal, y la infinita variedad, flexibilidad y destreza rítmica de su verso, en la que sobrepasa a cualquier otro poeta de nuestro idioma... (Henríquez Ureña, 2008: 211).

Con estas palabras tan repetidas, Pedro Henríquez Ureña encumbró a Rubén Darío como el gran poeta en lengua castellana de la contemporaneidad, ofreciendo además las principales claves de interpretación de la obra del vate nicaragüense, aquellas por las que ha sido imitado, criticado, versionado y distorsionado a lo largo de todo el siglo XX: sus imágenes coloridas — y sonoras-, la vasta cultura literaria del poeta, lector empedernido, la armonía de su verbo y la facilidad musical de los ritmos de sus versos.

Una de las líneas de investigación más felices de la tradición crítica dariana ha sido precisamente la del análisis de la interpretación que los poetas del siglo XX han realizado del magisterio de Rubén Darío. Los grandes intelectuales latinoamericanos del siglo, desde José Enrique Rodó hasta Octavio Paz (1964), han tenido que situar su identidad literaria, casi como una obligación, atendiendo al significado del nombre y de la obra de Rubén Darío. Algunos incluso, como Jorge Luis Borges (1967), pasaron de la feroz crítica juvenil a la madura admiración posterior, calificándolo como el «Libertador» de la literatura latinoamericana. Los estudios críticos han incidido en esta consideración del poeta como iniciador de la poesía latinoamericana contemporánea y han hecho hincapié en numerosas ocasiones en las diferentes influencias de la obra dariana en la poesía del siglo (Alemany, 2007). Entre los poetas españoles también se recibió la obra de Darío de una manera intensa y generosa, como muestran los numerosos trabajos que destacan las relaciones entre el poeta nicaragüense y los jóvenes poetas españoles de su tiempo, como Antonio Machado, Juan Ramón Jiménez, Francisco Villaespesa, Miguel Hernández, Federico García Lorca o Valle-Inclán, algunos de los cuales forman parte del análisis de este trabajo.

El objetivo de estas líneas, además de continuar esta senda crítica de las influencias modernistas en los jóvenes poetas de la primera mitad del siglo $\mathrm{XX}$, es plantear un ejercicio de comentario de texto de poemas que Rubén Darío, por fechas, no pudo escribir, que pertenecen a tres autores imprescindibles de la poesía española contemporánea. Se presentarán primero los textos, sin desvelar el nombre del autor ni el contexto de producción y se 
desgranarán a continuación a partir de las características definitorias de la poesía de Rubén Darío establecidas por Henríquez Ureña.

Aquello que la tradición historiográfica ha sancionado como Modernismo no puede ser un conjunto de características memorizables y repetidas en un examen semestral, sino un contexto literario y cultural que surge a partir de la publicación de algunas obras de autores principales como Rubén Darío y que se refleja en testimonios de autores coetáneos como Antonio Machado, Francisco Villaespesa o Juan Ramón Jiménez. El contexto de producción es imprescindible, sí, pero no debemos olvidar que el punto de partida ha de ser la interpretación de los textos. Ser las lenguas, los comentaristas, de esos mudos maestros que son los libros, como escribiera el maestro Alejo de Venegas en el siglo XVI.

Así pues, diseño a continuación un pequeño juego de comentario de texto de tres poemas de tres autores españoles esenciales que parte de la justificación acerca de por qué Rubén Darío pudo o no escribirlos. Aunque algunos poemas son bastante conocidos, se mantienen en secreto los nombres de los autores hasta la segunda parte de los comentarios, en los que se abordan los contextos de producción y el análisis ideológico.

\section{1. «A la muerte de Rubén Darío»}

Si era toda en tu verso la armonía del mundo, ¿dónde fuiste, Darío, la armonía a buscar?

Jardinero de Hesperia, ruiseñor de los mares, corazón asombrado de la música astral, ite ha llevado Dionisos de su mano al infierno y con las nuevas rosas triunfantes volverás? ¿Te han herido buscando la soñada Florida, la fuente de la eterna juventud, capitán? Que en esta lengua madre la clara historia quede; corazones de todas las Españas, llorad.

Rubén Darío ha muerto en sus tierras de Oro, esta nueva nos vino atravesando el mar. Pongamos, españoles, en un severo mármol su nombre, flauta y lira, y una inscripción no más: Nadie esta lira pulse, si no es el mismo Apolo; nadie esta flauta suene, si no es el mismo Pan.

A) ¿Por qué Rubén Darío pudo escribir este poema? Comentario estilístico Quizá sean estos versos el mejor homenaje al significado de la vida y la obra de Rubén Darío escritos tras su muerte en su país natal en 1916. Y quizá 
lo sean porque existen numerosas particularidades estilísticas que permiten crear la ficción de que el propio Rubén pudo haberlos firmado, publicados hace ahora un siglo.

La destreza rítmica del poema nos recuerda claramente al armonioso verso dariano, vertebrado a través de una estructura arromanzada en alejandrinos en la que destaca la acentuación aguda de los versos pares. Los alejandrinos, perfectos en su hechura, mantienen la división en dos hemistiquios heptasilábicos con cesura y rima interna (Sie ra tó daen tu vér so / laar mo ní a del mún do, 7), que en la tradición hispánica, como sabemos, fueron característicos de la poesía medieval del mester de clerecía.

La articulación métrica del poema es propiamente modernista, como muestran algunos de los sonetos en alejandrinos más conocidos del poeta: «Caupolicán» por ejemplo, o «Amado Nervo», que además de ser también un homenaje literario utiliza el mismo pie métrico que el poema propuesto a partir de la tergiversación de la rima clásica del soneto que se convierte en una estructura arromanzada de rima aguda:

Amado es la palabra que en querer se concreta;

Nervo es la vibración de los nervios del mal.

¡Bendita sea y pura la canción del poeta que lanzó sin pensar su frase de cristal!...

Fraile de los suspiros, celeste anacoreta, que tienes en blancura l'azúcar y la sal, muéstrame el lirio puro que sigues en la veta, y hazme escuchar el eco de tu alma sideral

(Darío, 2007: 1199).

El verbo dariano también es fácilmente reconocible en el poema, pues el léxico del Modernismo, como sabemos, creó algunos lugares comunes. Las palabras sonoras por su composición morfológica y fonética destacan en el texto («armonía», «astral», «jardinero», «juventud», «soñada», «ruiseñor», «inscripción», «música»), así como otras que, también por su significado, nos remiten a los movimientos de los que bebió Rubén Darío (Romanticismo, Simbolismo, Decadentismo, Parnasianismo) y a partir de los cuales moduló el Modernismo un léxico característico: «capitán», «severo mármol», «eterna», «jardinero», «tierras de oro», «nuevas rosas», «flauta», «lira». Buena parte de esta imaginería modernista se puede recuperar por ejemplo en el conocido poema que abre Cantos de vida y esperanza «Yo soy aquel que ayer no más decía» (Darío, 2007:245), en el que el poeta nicaragüense revisa su trayectoria vital y literaria y en el que se plantea también un juego metapoético de descripción y análisis del programa estético de las obras anteriores. 
Otra de las grandes cuestiones que destacan en el poema propuesto son las alusiones culturalistas a la mitología clásica, tan del gusto de Darío. Aquello que Henríquez Ureña denominaba la riqueza de las alusiones literarias y que sin duda se convierten en una de las claves de interpretación de la estética modernista. Recordemos, por ejemplo, la asimilación del esplendor de la nueva poesía con la belleza de Helena en «El cisne» de Prosas profanas («Bajo tus alas blancas la nueva Poesía / concibe en una gloria de luz y de harmonía / la Helena eterna y pura que encarna el ideal», (Darío 2007:202)). En este caso, el poema alude al dios Dionisos y bautiza al poeta como «jardinero de Hesperia», en otra clara alusión mitológica que desarrollaremos más adelante. Sin duda, la referencia mitológica que mejor vertebra el poema es la construida en los últimos versos, cuando el poeta alude al severo mármol y al epitafio: «Nadie esta lira pulse, si no es el mismo Apolo / nadie esta flauta suene si no es el mismo Pan». La fantástica aliteración que reitera el sonido sibilante para emular la música de los instrumentos rememora la historia de Apolo y Pan, que Rubén Darío había utilizado también en alguna ocasión, como por ejemplo en las «Palabras a la satiresa» de Prosas Profanas, que parecen ser la fuente del poema que se analiza.

Tú que fuiste, me dijo, un antiguo argonauta, alma que el sol sonrosa y que la mar zafira, sabe que está el secreto de todo ritmo y pauta en unir carne y alma a la esfera que gira, y amando a Pan y Apolo en la lira y la flauta, ser en la flauta Pan, como Apolo en la lira (Darío 2007:230).

\section{B) ¿Por qué Rubén no pudo escribir este poema? Comentario ideológico}

Rubén Darío no pudo escribir este homenaje a su muerte, claro, porque fue compuesto por Antonio Machado y publicado en la sección «Elogios» de Campos de Castilla en el año 1917. La relación entre Machado y Darío ha sido estudiadísima entre otros por investigadores de la talla de Oreste Macrí (1972), Aurora de Albornoz (1986), Ricardo Gullón (1961) o el propio Juan Ramón Jiménez. Ricardo Gullón llegó afirmar incluso que Machado fue «quizá (contra lo que decían leyendas caducas) el más rubendariano de los modernistas españoles» (1969: 25), rescatando una relación intelectual intensa y de admiración entre ambos. Se conocieron en París en 1902 (Albornoz, 1986: 249), en el primer viaje de Rubén Darío a la capital francesa, donde comenzó un intercambio de poemas que inició Antonio Machado en 1904 con «Al maestro Rubén Darío» y continuó el vate nicaragüense con textos como «Caracol» de «Otros poemas» de Cantos de vida y esperanza o el poema 
que inicia «Misterioso y silencioso / iba una y otra vez» publicado en El canto errante. Aurora de Albornoz (1986) se ha encargado de estudiar las semejanzas y las diferencias del verso que Machado guardaba en su abrigo tras su desventurada muerte en Colliure en 1939, huyendo de la Guerra Civil. Si se acordó Machado o no de Darío en sus últimos días quizá no sea tan importante como entender esta intensa relación intelectual, pues los versos de ensoñación darianos «En los días de azul de mi dorada infancia / yo solía pensar en Francia y en Bolivia; / en Francia hallaba néctar que la nostalgia alivia, / y en Bolivia encontraba una arcaica fragancia» del soneto «A Bolivia» (Darío, 2007:1116) distan mucho de la trágica sensación machadiana del recuerdo de la infancia, dejando atrás un país destrozado «Estos días azules y este sol de la infancia...». Sin embargo, al menos en cierta medida, no pueden entenderse sin la poética dariana.

Una vez desvelado el autor el siguiente paso sería enfrentarse al comentario ideológico del poema a partir de las diferentes claves de interpretación del mismo. Las líneas de comentario planteadas a continuación podrían significar bien desarrolladas un artículo por sí solas, pero el objetivo aquí es otro, por lo que simplemente enunciaré algunas referencias que permitan insertar el texto en sus contextos de interpretación.

Uno de los versos axiales del poema de Machado es el verso 10: «Corazones de todas las Españas, llorad». En él encontramos un imperativo enfático al final de verso que nos recuerda a otro de los «Elogios» publicados en Campos de Castilla y que Machado escribe también en estos años, homenajeando con maestría a Juan Ramón Jiménez, a Unamuno, a Azorín, a Darío, claro, y también a su maestro en la Institución Libre de Enseñanza, a don Francisco Giner de los Ríos. Así precisamente se titula el poema, «A don Francisco Giner de los Ríos», en el que el poeta sevillano pone en boca del maestro un discurso directo en el que se suceden los imperativos como marca recurrente del estilo machadiano de esta época: «Sed buenos y no más...»; «Vivid, la vida sigue...» o «iYunques, sonad; enmudeced, campanas!» (Machado, 1999:237)

El verso siguiente, «Rubén Darío ha muerto en sus tierras de Oro», introduce otro de los lugares comunes del Modernismo y de la poética dariana: la recreación del mito de El Dorado en el continente americano y la utilización del oro como elemento esencial de la imaginería modernista. El verso puede entenderse como una alusión geográfica evidente a su tierra natal, como el propio Darío escribió en el poema «Allá lejos» de Cantos de vida y esperanza: «Buey que vi en mi niñez echando vaho un día / bajo el nicaragüense sol de encendidos oros» (Darío 2007:311) pero la mayúscula que utiliza Machado puede remitir también a unas tierras de Oro en la ensoñación del poeta, que 
recreó en textos como «La canción del oro», de Azul, o en menor medida en las composiciones en prosa dedicadas a Mallorca La isla de Oro (1907) y El oro de Mallorca (1913).

En la segunda estrofa del poema Machado plantea una pregunta retórica en la que insinúa el descenso a los infiernos del poeta de la mano de Dionisos y su regreso con las «rosas triunfantes» de la nueva poesía. La rosa fue la flor sagrada de la mitología griega y aunque su origen y su representación más recurrente la asocian a la belleza de Afrodita, existe alguna versión que habla de Dionisos como el creador de la rosa (Gómez Gallego, 2009). La personificación de Darío como actor del descenso a los infiernos le sitúa al nivel de Odiseo o de Orfeo, regresando como revelador de la nueva poesía, simbolizada con las «rosas triunfantes». La asimilación de la rosa con el afrancesamiento de la poesía de su tiempo es recurrente en la poesía de Machado. Así, en el poema de 1904 que le dedica «Al maestro Rubén Darío» el poeta sevillano ya plantea la relación entre Darío y las rosas, rescatando al poeta renacentista francés Pierre de Ronsard, conocido por sus Sonetos a Helena, donde reescribe el collige virgo rosas de Ausonio. Este es el fragmento, donde encontramos también algunas referencias reiteradas en el texto que nos ocupa:

Este noble poeta, que ha escuchado

los ecos de la tarde y los violines

del otoño en Verlaine,

y que ha cortado

las rosas de Ronsard en los jardines

de Francia, hoy, peregrino

de un Ultramar de Sol, nos trae el oro

de su verbo divino

(Machado, 1997:261).

La imagen del jardín de las rosas de Ronsard la repite Machado en su conocido «Autorretrato» en una metáfora en la que trata de explicar su filiación poética y en la que se atribuye también la influencia francesa de «las viejas rosas del huerto de Ronsard» frente a «los afeites de la actual cosmética» (Machado, 1999:101). La misma metáfora para definir los dos programas poéticos, el de Darío y el suyo propio.

En el verso tercero Machado utiliza otro de los lugares comunes de la estética simbolista del Modernismo, el jardín, para bautizar a Darío como «Jardinero de Hesperia». La importancia del jardín como símbolo vertebrador del arte modernista queda patente en las innumerables referencias que podemos encontrar en la obra del propio Darío. Rescato un pequeño ejemplo, un pasaje de La isla de Oro interesante porque es el mismo poeta quien define lo que para él representa el jardín y porque además transcribe un fragmento de 
otro de los grandes escritores modernistas, Santiago Rusiñol, hablando del «jardiner poeta» creador de «simètriques harmonies»:

—Señora —interrumpí-, los jardines son y han sido siempre un incomparable tema para poetas y para filósofos. Aún respiramos tamizados por los siglos los perfumes de Academo. En cuanto a la jardinería, puede ser considerada como una de las bellas artes. Antes que un Le Nôttre o un La Quintinie, aprobaría mi decir un poeta anglosajón hermano de los ángeles y de nombre Edgar Poe.

Rusiñol lanzó una bocanada de humo. Y como se hablase de la decadencia de los jardines, se levantó y leyó en el bello libro en su lengua vernácula: «...I és que els jardins són el paisatge posat en vers, i els versos escrits en plantes van escassejant pertot arreu; es que els jardins són versos vius, versos amb saba i amb aroma; i com el jardiner poeta, per a rimar els llargs caminals ombrívols, per a estilitzar els boixos fent-los seguir simètriques harmonies, per a posar en estrofes de verdor les imatges de les plantes i les teories de figures, per a versificar la Natura i fer cants d'ombres i clarors, necessita de l'alegria dels temps i de la prosperitat deis homes, i els homes, ai!, ja no estan per a poesies, ni els temps per a magnificències, els versos escrits en el jardí se van omplint d'herba de prosa, en l'aspre terrer d'Espanya». (La isla de Oro, 1969)

Podríamos seguir desmenuzando el texto y analizar influencias y recepciones, estirar otras significaciones y ampliar las establecidas. No obstante, concluimos aquí este primer ejercicio en el que se han trazado influencias cruzadas entre dos de las voces más destacadas de la poesía hispánica contemporánea a partir de la lectura crítica de los detalles del verso, tanto en su comentario estilístico como en su comentario ideológico.

\section{2. «Granada (elegía humilde»)}

Elegía, Granada, la dicen las estrellas que horadan desde el cielo tu negro corazón.

La dice el horizonte perdido de tu vega, la repite solemne la yedra que se entrega a la muda caricia del viejo torreón.

Tu elegía, Granada, es silencio herrumbroso, un silencio ya muerto a fuerza de soñar.

Al quebrarse el encanto, tus venas desangraron el aroma inmortal que los ríos llevaron en burbujas de llanto hacia el sonoro mar.

El sonido del agua es como un polvo viejo que cubre tus almenas, tus bosques, tus jardines, agua muerta que es sangre de tus torres heridas, agua que es toda el alma de mil nieblas fundidas que convierte a las piedras en lirios y jazmines. 
Hoy, Granada, te elevas ya muerta para siempre en túmulo de nieve y mortaja de sol, esqueleto gigante de sultana gloriosa devorado por bosques de laureles y rosas ante quien vela y llora el poeta español.

Hoy, Granada, te elevas guardada por cipreses (llamas petrificadas de tu vieja pasión). Partió ya de tu seno el naranjal de oro, la palmera extasiada del África tesoro, solo queda la nieve del agua y su canción.

Tus torres son ya sombras. Cenizas tus granitos, pues te destruye el tiempo. La civilización pone sobre tu vientre sagrado su cabeza, y ese vientre que estuvo preñado de fiereza, hoy aún muerto se opone a la profanación.

Tú que antaño tuviste los torrentes de rosas, tropeles de guerreros con banderas al viento, minaretes de mármol con turbantes de sedas, colmenas musicales entre las alamedas y estanques como esfinges del agua al firmamento.

Tú que antaño tuviste manantiales de aroma donde bebieron regias caravanas de gente que te ofrendaba el ámbar a cambio de la plata, en cuyas riberas teñidas de escarlata las vieron con asombro los ojos del Oriente.

Tú, ciudad del ensueño y de la luna llena, que albergaste pasiones gigantescas de amor, hoy ya muerta, reposas sobre rojas colinas teniendo entre las yedras añosas de tus ruinas el acento doliente del dulce ruiseñor.

¿Qué se fue de tus muros para siempre, Granada? Fue el perfume potente de tu raza encantada que dejando raudales de bruma te dejó. ¿O acaso tu tristeza es tristeza nativa y desde que naciste aún sigues pensativa enredando tus torres al tiempo que pasó?

Hoy, ciudad melancólica del ciprés y del agua, en tus yedras añosas se detenga mi voz. ¡Hunde tus torreones! Hunde tu Alhambra vieja que ya marchita y rota sobre el monte se queja, queriendo deshojarse como marmórea flor. 
Invaden con la sombra maciza tus ambientes.

¡Olvidan a la raza viril que te formó!

Y hoy que el hombre profana tu sepulcral encanto, quiero que entre tus ruinas se adormezca mi canto como un pájaro herido por astral cazador.

\section{A) ¿Por qué Rubén Darío pudo escribir este poema?}

El segundo poema propuesto para el comentario se llama «Granada, elegía humilde» y desde el mismo título, que apunta hacia el simbolismo de las ciudades muertas de finales del siglo XIX, podemos rescatar imágenes y recursos estilísticos propios de la estética modernista. Por su rareza, he transcrito el poema de la edición original, de la que después daré cuenta.

El poema, como se observa, se articula a partir de una tirada de versos agrupados en estrofas de cinco. El metro utilizado es de nuevo el alejandrino, y la estructura de cuarteto de la rima consonante, dejando libre de rima el primer verso de cada estrofa, sitúa al poema en la onda de las hechuras darianas, repitiendo en algunas estrofas, como en el poema de Machado, la acentuación aguda del verso: «Hoy, Granada, te elevas ya muerta para siempre / en túmulo de nieve y mortaja de sol, / esqueleto gigante de sultana gloriosa / devorado por bosques de laureles y rosas / ante quien vela y llora el poeta español».

Aunque el poema debe mucho en su construcción léxica a la influencia de Francisco Villaespesa, sobre todo a los versos de «Las fuentes de la ciudad» (Ceba, 1990) y José Zorrilla (Merlo, 2007: 90) se pueden rescatar también tópicos de la felicidad verbal propia de la estética rubendariana. Así, de nuevo encontramos sonidos, construcciones sintácticas y significaciones a lo largo de todo el poema que recuerdan la articulación fonética, sintáctica y semántica del Modernismo. En este sentido, llama la atención, entre otras, la utilización del epíteto «marmórea flor» en el quinto verso de la penúltima estrofa: «queriendo deshojarse como marmórea flor». La imagen, fantástica en la construcción de la antítesis, se convirtió en lugar común entre los poetas modernistas. La misma asimilación del mármol y la flor aparece en el poema «Metempsicosis» de Rubén Darío, en el que habla del lecho de la reina Cleopatra y en cuyo último verso suena: «¡Oh, la rosa marmórea omnipotente» (Darío, 2007:331) En la transcripción del poema, marcamos en negrita aquellas palabras, construcciones o versos de clara influencia modernista, como «estanque», «ensueño de la luna llena», «astral cazador», etc., sin incidir en sus posibles fuentes. Aunque abriría nuevas y buenas perspectivas de análisis, el mecanismo de interpretación es el mismo que ya realizamos en el comentario del poema machadiano. 
Siguiendo las pautas de Henríquez Ureña, el poema se construye también a partir de referentes culturales de época que el joven autor del texto asume por ejemplo en la construcción simbólica de la ciudad. El poema que nos ocupa es un canto indiscutible a la ciudad, a una ciudad muerta llamada Granada, cuya tradición entronca perfectamente con las alusiones literarias de las que bebió también la poética dariana, como decíamos. «isí empecé en francés, pensando en Rodenbach...», (Darío, 2007:377) escribe Rubén Darío en la «Epístola a la señora de Lugones», destacando la influencia simbolista del autor de Brujas, la muerta, que es también la base argumental y estética del poema que nos ocupa.

\section{B) ¿Por qué Darío no pudo escribir este poema?}

Este canto a Granada de tono simbolista y de herencia romántica lo escribió un joven llamado Federico García Lorca en torno al año 1919. Lorca tenía apenas veinte años y como hemos argumentado en las líneas anteriores el ideario estético del joven poeta estuvo decididamente marcado por el imaginario formal modernista. Federico García Lorca acudía por entonces a la tertulia del café Alameda junto a un grupo de intelectuales en sintonía con las novedades editoriales de su época y en torno a varias revistas y periódicos como el Renovación (Merlo, 2007:89). Gallego Morel, hijo de Antonio Gallego y Burín, director del periódico Renovación, editaba por primera vez el texto en el Bulletin Hispanique bajo el título «El primer poema publicado por Federico García Lorca» (1967) desde su publicación en el periódico el 25 de junio de 1919. Así definía su significado: «Es un poema del Lorca de entonces [poeta inédito que comienza su contacto con los intelectuales granadinos entre otros en este medio de prensa]. Con el ademán de poeta civil que ha contagiado a todos los jóvenes Rubén Darío y con la herencia modernista que Lorca tiene más a mano: la del almeriense Francisco Villaespesa» (1967, p. 488).

Muchos han sido los trabajos que se han acercado al Lorca juvenil (García Montero, 1997; García Lorca, 1980), aunque sobre las relaciones entre el poeta granadino y Darío destacan los estudios recientes de María José Merlo (2007), sobre todo aquellos relacionados con la interpretación del Diván del Tamarit, en el que el último Lorca decididamente había asumido el imaginario dariano, no ya como una concepción inicial del adolescente que se está iniciando en la poesía, como en los versos que nos ocupan, sino como una recurrencia significativa profunda que articula el discurso lírico del poeta granadino.

Merlo destaca los rasgos modernistas del poema de Lorca: «desde la añoranza y el llanto por la pérdida de una civilización muy concreta, la de Oriente, tan cantada por los poetas modernistas y exaltada por el propio Rubén, 
hasta toda una serie de poetas fulgurantes» (2007: 90) y en el artículo trae a colación también el testimonio de Francisco García Lorca en Federico y su mundo acerca de estos años iniciales del poeta, en el que llenaba cuartillas con avidez, destacando que «la sombra del maestro Rubén se proyecta inspiradora en el entonces balbuciente poeta» (García Lorca en Merlo, 2007: 90). Sobre la admiración de Lorca por Darío, además los rasgos de su obra, nos queda la lectura del famoso discurso «al alimón» que impartieron Pablo Neruda y Federico García Lorca en Buenos Aires en el que reivindican el valor y el significado de Darío para la poesía hispánica:

Como poeta español enseñó en España a los viejos maestros y a los niños, con un sentido de universalidad y de generosidad que hace falta en los poetas actuales. Enseñó a Valle Inclán y a Juan Ramón Jiménez, y a los hermanos Machado, y su voz fue agua y salitre, en el surco del venerable idioma. Desde Rodrigo Caro a los Argensolas o don Juan Arguijo no había tenido el español fiestas de palabras, choques de consonantes, luces y forma como en Rubén Darío. Desde el paisaje de Velázquez y la hoguera de Goya y desde la melancolía de Quevedo al culto color manzana de las payesas mallorquinas, Darío paseó la tierra de España como su propia tierra (García Lorca, s.f.).

En este caso las líneas de interpretación principales del comentario ideológico del poema están relacionadas por la escritura del tópico de la ciudad muerta y sus diferentes interferencias estéticas, que provocan la asunción de postulados románticos y simbolistas que tan bien filtraron los poetas modernistas.

No hay duda de que la escritura de García Lorca es en sus recurrencias temáticas un gran canto a Granada. El gran lienzo de la modernidad sobre la ficcionalización de una ciudad íntimamente ligada a la producción artística que, por su mestizaje cultural y la grandiosidad de su legado, ha sido centro de atracción e inspiración de numerosos artistas. Efrén Ortiz recorre algunos momentos en los que la poesía trata de construir el imaginario de la ciudad y destaca este poema como un canto insertado en una tradición cultural, la del final de una época y la crisis finisecular, que poco tiene que ver con el regionalismo de las imágenes posteriores del Lorca del Poema del cante jondo o el Romancero Gitano:

He subrayado la importancia de esta composición no sólo por el hecho de que está dedicada de manera íntegra a la ciudad, sino porque el tono, el contenido y los motivos que ella utiliza son radicalmente distintos de aquellos con los que tradicionalmente identificamos a García Lorca: aquí no hallamos solamente gitanos, cantores ciegos, toreros o andaluzas, es decir, la ciudad no es el motivo estereotipado de corte regionalista, ni el bosquejo de una topografía y una arquitectura posible de fincar en un periodo histórico, sino más bien la oportunidad para hablar acerca de un momento de crisis histórica, del cual la ciudad funge como escenario y emblema (Ortiz, 2012). 
No es momento para profundizar en una tradición, la de la ciudad muerta, trabajada de manera excelente por especialistas como Miguel Ángel Lozano (1994) o Eva Valero (2005), tan solo esbozar la evidente filiación del poema lorquiano con el topos enunciado por Rodenbach y asumido por los poetas modernistas, como decíamos líneas atrás. Eva Valero describe el tópico en toda su extensión, que muchos, como el joven Lorca en el poema que nos ocupa, imitaron como ejercicio poético inicial de época:

Es en la obra de Rodenbach titulada significativamente Brujas la muerta (1892), donde el motivo se convierte en topos reconocible. La imagen es muy concreta: es la ciudad melancólica y brumosa, con su hechizo de horizontes tristes y grisáceos, la vaguedad impresionista en el ensueño de sus calles o su moroso ritmo de lugar adormecido; en una, una ciudad provinciana y murmuradora cuyo sonido opaco de campanas es su lenguaje y se fusiona con el mortecino silencio de su ambiente.

La combinación de todos estos rasgos exacerba la concepción literaria de la urbe como objetivo último, a través de la creación de la ciudad como estado de ánimo. En ella, la hiperestesia de los sentidos deriva en un proceso de introspección que identifica finalmente las peculiaridades sensitivas de la ciudad con las del propio personaje (Valero, 2005:707).

La configuración de esta Granada humilde y mortecina de 1919 debe por tanto su configuración a la idealización de la ciudad propia de la tradición romántico-simbolista, manifestada a través de la construcción de una elegía. En 1899, por ejemplo, se publica una miscelánea de textos e ilustraciones titulada Libro de Granada, en la que participaron entre otros Ángel Ganivet o Isidoro Marín, y en la que se da cuenta de esta Granada decadentista asimilada a la Brujas de la pintura de Fernand Khnopff, que Lorca debió conocer de primera mano. El propio Darío, además, escribió sobre sus sensaciones sobre la ciudad de Granada, recogidas en un artículo publicado en Tierras solares, donde se pueden leer sugestiones idealistas como la siguiente: «cuando he venido a la ciudad de Boabdil, he tenido muy amables imaginaciones. He pensado en visiones miliunochescas» (Darío, 1991:97), que evidentemente marcaron la proyección estética de esta primera Granada de Federico García Lorca.

El topos de la ciudad muerta tiene en buena medida una estrecha vinculación con algunos temas recurrentes que el siglo XIX cribó de la tradición hispánica y latina. Por ejemplo, en el texto se observan elementos claramente rastreables en la lírica renacentista de la poesía de ruinas, que a su vez se configura a partir de tópicos latinos como el ubi sunt. Como en la Canción a las ruinas itálicas, emblema hispánico de una tradición de origen latino (Ferri, 1995) el poema de Lorca tiene constantes vocativos a la ciudad «Elegía, 
Granada, la dicen las estrellas», que se presenta personificada como destinataria del poema: «Tú que antaño tuviste...» y en la que suenan las trágicas preguntas retóricas del ubi sunt: «¿Qué se fue de tus muros para siempre, Granada?» y resuenan las respuestas fatales del tiempo todo lo muda: «Tus torres son ya sombras. Cenizas tus granitos, pues te destruye el tiempo».

Otra de las líneas de interpretación de esta ciudad lorquiana es el análisis del simbolismo de uno de los elementos más característicos de su íntimo imaginario estético, el agua. Lorca esboza en el poema una ciudad del agua, que rige y vertebra el estado de ánimo de la Granada recreada. La alusión a los estanques, a las fuentes, al «agua muerta» se convierte en un símbolo, en una metáfora cósmica, que asocia la podredumbre decadentista con la sensación de tristeza del habitante de esa ciudad que impulsan los versos. En el poema que nos ocupa podemos leer:

El sonido del agua es como un polvo viejo que cubre tus almenas, tus bosques, tus jardines, agua muerta que es sangre de tus torres heridas, agua que es toda el alma de mil nieblas fundidas que convierte a las piedras en lirios y jazmines.

Rubén Darío, en el ya citado relato sobre Granada publicado en Tierras solares, focalizaba también su atención en este hito vertebrador de la ciudad con un tono de admiración evidente: «El agua por todas partes, en las copiosas albercas, en los estanques que reproducen las bizarrías arquitecturales, en las anchas tazas como la que sostienen los leones del famoso patio, o simplemente brotando de los surtidores colocados entre las lisas losas de mármol» (Darío, 1991: 101). Y el propio Lorca, como destaca el análisis de María José Merlo (2007: 97) no dejó nunca de reflexionar en sus diferentes manifestaciones artísticas sobre la importancia y la significación de ese símbolo que aparece ya reflejado en este poema inicial. Merlo (2007) recoge el testimonio de Lorca en una carta a Melchor Fernández Almagro en la fecha temprana de 1922, en la que el poeta transmite fascinado su interés por las posibilidades artísticas que se abren ante el agua de Granada, que nos valdrían para iniciar un comentario más amplio sobre este tema:

He visto un libro admirable que está por hacerse y quisiera hacerlo yo. Son Las meditaciones y alegorías del agua. El poema del agua que mi libro tiene se ha abierto dentro de mi alma. Veo un gran poema entre oriental y cristianoeuropeo del agua [...]. Y luego cuando trate del agua muerta, iqué poema tan emocionante el de la Alhambra vista como panteón del agua (Lorca en Merlo, 2007: 97). 


\section{Balada de juventud [fragmento]}

Llegó a mí triunfante: la vi, y la sorpresa como un licor grato mi alma embargó... ¿Quién eres?... - -le dije: ¿Divina princesa? ¿Hermoso fantasma? - Su boca de fresa se abrió dulcemente y así musitó:

«Soy el hada blanca que deja el camino fatal de la Vida regado de luz; que enciende en las almas un fuego divino; que oculta al humano su pobre destino y de su existencia suaviza la cruz.

Yo soy roja rosa que se abre lozana al cálido beso del sol del Abril; yo soy de la Vida la Aurora galana naciendo entre nubes de ópalo y grana, naciendo entre perlas y aljófares mil.

Yo soy sueño cándido; yo soy fuente viva que va fugitiva por campo feraz; yo soy dulce abeja zumbante y activa que a todas las flores sus néctares liba; yo soy nube de oro que pasa fugaz.

Yo soy fuerte hoguera que inmensa se inflama la sangre en las venas haciendo rugir; poniendo en los ojos reflejos de llama, los pechos cubriendo de ignífera escama, haciendo gozosas las fibras crujir.

Mi aliento da al viento más notas que el ave, mi vida está urdida con una ilusión; del cruel desengaño mi pecho no sabe; en mí la sombría Tristeza no cabe; en mi alma la Pena no encuentra mansión.

Alcázares finjo más altos que montes; escalo las bóvedas de ingrávido tul asida a las ruedas de alados Faetones; ensueño quimeras; oteo horizontes de nieve, de rosa, de nácar, de azul.

Yo soy gentil góndola que llégase henchida de fe y de optimismo al fondo del mar; yo soy copa llena de ardiente bebida; yo soy del gran libro que forma la Vida la página de oro que puede mostrar. 
No encuentro en mi senda traidores abrojos, ni zarzas rastreras, ni acíbar, ni hiel; la encuentro alfombrada de pétalos rojos de ufanos claveles, de hilados embojos, de luz, de alegría de rosas, de miel.

De fúlgidas luces empapo los días; los tristes crepúsculos de gayo color; los huecos espacios de un mar de armonías y un mar de fragancias; las noches sombrías de encantos, de risas, de besos, ¡de amor!

Yo soy virgen casta que todos adoran, que todos aguardan con viva inquietud; yo soy manjar rico que todos devoran; amante a quien todos suspiran y lloran cuando huye a otros brazos; ¡yo soy Juventud!»

Al oírla, a mis ojos un mundo risueño vi abrirse, a mis plantas hallé dichas mil... Mas, cuando ya de ella creíame dueño, de mí se alejaba lo mismo que un sueño, lo mismo que un soplo de brisa sutil...

A veces me digo con honda tristeza:

¿Vendrá a mí aún el hada bendita que huyó?...

Mi frente surcada, mi cana cabeza

y el fuego de mi alma que a helarse ya empieza, responden con mudas palabras: ¡ $\mathrm{No}$ ! ${ }_{\mathrm{iN}} \mathrm{N}$ !

\section{A) ¿Por qué Rubén Darío pudo escribir este poema?}

El tercer poema del comentario, esta «Balada de la juventud», es también un ejercicio de imitación rubeniano de formación que responde a los patrones formales e ideológicos del Modernismo. De nuevo, tanto la destreza rítmica, como la felicidad verbal como las referencias literarias de las que partíamos para el análisis se cumplen de una manera evidente. En este texto, incluso, las referencias son más explícitas.

Los versos se agrupan en quintetos dodecasílabos dactílicos que en este caso responden a la estructura de rima ABBBA. De nuevo aparecen versos agudos y un patrón acentual reiterativo, separando el verso en dos hemistiquios que, junto a la rima, provocan la musicalidad del texto. La vertebración rítmica de los famosos versos medievales de Juan de Mena: «Al muy prepotente don Juan el segundo, / aquel con quien Júpiter tuvo tal celo...» fueron 
adaptados por Rubén Darío al pie dactílico y reiterados por los poetas modernistas. Muy conocidos son los versos autorreferenciales de Amado Nervo a este respecto: «El metro de doce son cuatro donceles / donceles latinos de rítmica tropa; / Son cuatro hijosdalgo con cuatro corceles; /El metro de doce galopa, galopa» (Nervo, 2005).

La carga léxica del poema debe mucho en su construcción a la Rima XI de Bécquer «Yo soy ardiente, yo soy morena, / yo soy el símbolo de la pasión», pero sobre todo a la «Sonatina» de Rubén Darío, a la que el poeta alude directamente: «¿Quién eres?... - le dije: ¿Divina princesa? / ¿Hermoso fantasma? - Su boca de fresa». Un análisis exhaustivo del texto propondría una vinculación estrecha con las formas del Modernismo, cuyas imágenes aparecen reiteradas con las bridas del dodecasílabo. Hadas, princesas tristes, fuego divino, ópalo y grana, ingrávido tul, fúlgidas luces, alegría de rosas, traidores abrojos, de nieve, de rosa, de nácar, de azul, forman una serie de construcciones de clara intertextualidad dariana. Encontramos también adjetivos antepuestos, esdrújulas sonoras, aliteraciones, mayúsculas significativas o enumeraciones ascendentes acabadas en exclamación, tan familiares, como esas palabras finales del poema « ¡No! ¡No!» que nos remiten a la estructura de la «Oda a Roosevelt». Las referencias literarias en este caso también aparecen, como las imágenes de la mitología griega referidas a Faetón o las Hadas, que aderezan el proyecto esteticista del poema.

\section{B) ¿Por qué no pudo escribir Rubén Darío este poema?}

El poema lo escribió un joven llamado Miguel Hernández, y apareció publicado en Orihuela en 1930 en el periódico El Pueblo de Orihuela, en el número 134 (Fernández Palmeral, 2005). Sobre cómo Miguel Hernández devoró en su juventud a Rubén Darío han hablado entre otros Juan Cano Ballesta, Balcells (1997) o José Carlos Rovira (2011), que han analizado las influencias no solo de estos primeros poemas, sino también en obras como El rayo que no cesa o Perito en lunas. En su epistolario, además, Balcells destaca algunos testimonios a Ramón Sijé en los que incluso se intercambian textos (el soneto que empieza «Hermano mío, tú que tienes la luz, dame la mía...» y en los que Miguel Hernández muestra su predilección por el poeta nicaragüense como uno de sus modelos literarios.

Las huellas darianas aparecen con fuerza en estos versos de formación, a través de los cuáles Miguel Hernández forja su pluma de poeta. Quizá de manera intuitiva, Miguel Hernández está asumiendo aquí el programa estético del Modernismo como ejercicio de imitación poética, tan repetidos a lo largo 
de la tradición hispánica, mediante el cual el poeta se enfrenta por primera vez a las complicaciones del ritmo y a los vericuetos del dodecasílabo.

Podríamos lanzar también diferentes temas de análisis para el texto propuesto y completar así el comentario de los poemas que Rubén Darío (no) pudo escribir. En este caso, los versos configuran un sueño de tono romántico en el que la inspiración de Bécquer planea sobre los sonoros versos modernistas. Insertar el poema en el tema recurrente del sueño en la literatura o en el arte hispánico, o más concretamente su importancia en el imaginario del Romanticismo y del Modernismo, podría arrojarnos una línea de interpretación fructífera, vinculada a las poéticas de Bécquer y el propio Darío, quién recurrió al sueño en numerosas ocasiones. Y como en los ejemplos anteriores, desgranar esta hipótesis nos llevaría a la exégesis de un poema, que por otra parte, nos devolvería a la frase inicial de Henríquez Ureña. Igual que Machado, igual que Lorca, el joven Miguel Hernández aprendió a escribir bajo la inmensa sombra del jardín dariano:

De cualquier poema en español puede decirse con precisión si se escribió antes o después de él. Sus admiradores sintieron la fascinación de sus imágenes llenas de color, su riqueza de alusiones literarias, su felicidad verbal, y la infinita variedad, flexibilidad y destreza rítmica de su verso, en la que sobrepasa a cualquier otro poeta de nuestro idioma... (Henríquez Ureña, 2008: 211).

\section{Bibliografía citada}

Albornoz, A., «Rubén Darío en el último verso de Antonio Machado», Anales de literatura hispanoamericana, 15 (1986), pp. 247-254.

Alemany, C., «Versiones, revisiones y subversiones de la poesía de Rubén Darío en el siglo XX». Anales de literatura hispanoamericana, 36 (2007), pp. 137-152.

Balcells, J. M., «Rubén Darío y Miguel Hernández», Anthropos, 170-171 (1997) pp. 138-141.

Borges, J. L., «Mensaje en honor a Rubén Darío», Darío, BAAL, XXXIII (1967).

CEBA, J. J., «La Influencia de Villaespesa en la obra de Federico García Lorca», Boletín del Instituto de Estudios Almerienses. Letras, 9-10 (1990-1991), pp. 81-110. Recuperado de http://www.almediam.org/PDF/Villaespesa.pdf

Darío, R., La isla de Oro, en Páginas desconocidas de Rubén Darío, Montevideo, Biblioteca de marcha, 1969

- Obra poética, Madrid, Biblioteca Castro, 2011.

- Poesía completa, Madrid, Galaxia Gutemberg, 2007.

- Tierras Solares, Sevilla, Don Quijote, 1991.

FERnÁndez PAlmeral, R., Simbología secreta de »El rayo que no cesa» de Miguel Hernández, Alicante, Biblioteca Virtual Miguel de Cervantes, 2005. 
FERRI, J.M., Las ciudades cantadas: el tema de las ruinas en la poesía española del Siglo de Oro, Alicante, Universidad de Alicante, 1995.

Feustle JR, J. A., «El secreto de la satiresa», Actas del Sexto Congreso de la Asociación Internacional de Hispanistas [Toronto del 22 al 26 de agosto de 1977], Toronto, Department of Spanish and Portuguese, University of Toronto, 1980, pp. 239241. Recuperado de http://cvc.cervantes.es/literatura/aih/pdf/06/aih_06_1_061. pdf

Gallego Morel A., «El primer poema publicado por Federico García Lorca». Bulletin Hispanique, 69:3 (1967), 487-492. Recuperado de http://www.persee. fr/doc/hispa_0007-4640_1967_num_69_3_3918

García Lorca, F. y Neruda, P., Discurso al alimón sobre Rubén Darío, Chile: Universidad de Chile, [s.f.]. Recuperado de http://www.neruda.uchile.cl/discursoalimon.htm

GARCíA Montero, Luis, «El taller juvenil» en Andrés Soria (ed.), La mirada joven. Estudios sobre la literatura juvenil de Federico García Lorca, Granada, Universidad de Granada, 1997, pp. 84-85

GÓMEZ GAllEGO, D., «El origen de las rosas según la mitología clásica», 2009, en Sobre Leyendas [en línea]. Recuperado de http://sobreleyendas.com/2009/04/18/ el-origen-de-las-rosas-segun-la-mitologia-clasica/

Gullón, R., La invención del 98 y otros ensayos, Madrid, Ed. Gredos, 1969.

Henríquez Ureña, P., Historia cultural y literaria de la América Hispánica, (ed. Vicente Cervera Salinas), Madrid, Verbum, 2008.

Libro de Granada, texto de Ángel Ganivet, Gabriel Ruiz de Almodóvar, Matías Méndez Vellido, Nicolás María López; ilustraciones de Adolfo Lozano, Isidoro Marín, José Ruiz de Almodóvar, Rafael Latorre, Granada, Imp. Lit. Vda. e Hijos de P. V. Sabatel, 1899.

LOZANO, M. A., «Una visión simbolista del espacio urbano: la ciudad muerta», en José Carlos Rovira y José Ramón Navarro (eds.), Actas del I Coloquio Internacional «Literatura y espacio urbano» (1993), Alicante, Fundación Cultural CAM, 1994, págs. 60-73.

Machado, A., Campos de Castilla, Madrid, Cátedra, 1999.

Machado, A., Poesía completa, Madrid, Austral, 1997.

MACRÍ, O., «La presencia de Rubén Darío en Antonio Machado». Studi e informazione I, 1972, pp. 1-50.

Merlo, M. J., «Rubén Darío en García Lorca». Revista de Crítica Literaria Latinoamericana, 33:65 (2007), pp. 89-103.

Nervo, A. Los jardines interiores, Alicante, Biblioteca Virtual Miguel de Cervantes, 2005.

Ortiz Domínguez, E. «En tierra de ciegos cantores: Granada en la poesía hispánica». Ángulo recto, 4:2 (2012). Recuperado de http://pendientedemigracion. ucm.es/info/angulo/volumen/Volumen04-2/articulos06.htm 
PAz, O., El caracol y la sirena, México, Joaquín Mortiz, 1964.

Rovira, J. C., «Introducción», en Darío, R. Obra poética, Madrid, Biblioteca Castro, 2011.

VALERO, E., «El trastorno de los sentidos: emergencias de la ciudad muerta en la obra de Julio Ramón Ribeyro». En La literatura hispanoamericana con los cinco sentidos. A Coruña: AEELH, 2005, pp. 705-712. 